\title{
The Study of Online knowledge Sharing Behavior: Effect of Individual Motivation factors on Individual Performance in Higher Education Students
}

\author{
Ulfah Ahsanah, Lady Oktafia W, Ayu Kusuma Dewi, Yessy Artanti * \\ Department of Management, Universitas Negeri Surabaya, Surabaya, East Java \\ Indonesia
}

\begin{abstract}
Knowledge sharing behavior is an activity of exchanging information or spreading massages very quickly and broadly like a virus on a computer by using an interactive internet network. The use of interactive technology can be via e-mail, blogs, sites chat, online bulletin and social networking sites. However, there is still little researches that discussed individual motivation factors where the person finally decides to conduct online knowledge sharing activities in relation to the individual academic performance of students in the university. This study aims to examine the influence of interpersonal relationship theory, especially individual motivation factors consisting of need to belong, altruism, and personal growth on the online knowledge sharing behavior in order to increase the student academic performance. In this study researchers distributed online questionnaires to students in universities of Surabaya, East Java, Indonesia and analyzed using path analysis. The results state that the variables need to belong, altruism, personal growth have positive effects on the online knowledge sharing behavior and online knowledge sharing behavior has a positive effect on student academic performance.
\end{abstract}

Key words: Knowledge sharing behavior, need to belong, altruism, personal growth, individual academic performance

\section{INTRODUCTION}

At present, the development of information technology is increasingly influencing one's lifestyle. One of the most influential is social media. Social media is presented to make communication and various activities easier. The increasing use of social media globally results in marketers and researchers recognizing that social media is the most efficient tool because it is durable, has a long period of time, and is able to establish affiliations between business people and potential consumers globally [21].

The development of information technology has also encouraged people creating social networks that aim to improve their relationships with others through e-mail, mobile, and online networks (facebook, instagram, whatsapp and others). A review of several viral marketing theories shows that consumers' desire to build and strengthen social relationships is a determinant for engaging in knowledge sharing activities. Actively knowledge sharing among people is included in the concept of knowledge sharing behavior (KSB).

The existence of social media phenomena, the role of information becomes important, through the use of technological advances can be one of the breakthroughs to improve student academic achievement. Where the frequency of information exchange or knowledge sharing at this time is not only done directly (face to face) but can also be done online.

According to [10], there is still little research that discusses the role of social processes, where individuals finally decide to do online knowledge sharing activities. According to [1] more than 59\% of the public regularly distributes content online. Where should online knowledge sharing has become part of modern life such as sending articles in newspapers or magazines, sending YouTube videos, and sending reviews about things to others.

Furthermore [19] states that knowledge sharing activities is related to long-term performance and competitiveness. But the role of social media in academic matters is currently not desirable by students, because at present students prefer to use social media as entertainment/entertainment that fills their free time, such as sharing life stories on Instagram stories, snapchats, or viewing entertainment content on youtube.

The use of the internet is inseparable from the purpose of users in general, namely to conduct knowledge sharing activities. Researchers have done a lot of research on the motivations, benefits, and content that influence knowledge sharing behavior. But it is still very rare to show the relationship between knowledge sharing behavior and performance. This also becomes a challenge for researchers to develop a quantitative theory that shows the relationship between knowledge sharing behavior in college environment. By understanding how students carry out knowledge sharing activities in networks/groups and social media that are 
often used and the motivations underlying them, this will encourage stakeholders at the university level to be able to facilitate the process of knowledge sharing by providing a platform or information system which is more effective and achieves competitive advantage.

\section{LITERATURE REVIEW}

\section{1. Social media and social media marketing}

The development of social relations through communication in cyberspace almost has in common with the stages of social relations as they should in the real world. Although there are some differences, the stages in social media are represented by several media systems that replace the role of verbal and non-verbal communication, namely text, graphics, images, audio, and video. Social media is a platform that is easily accessible to anyone. Even today someone who is independent of the company's role and control can create their own content that is interesting and seen by many people [24]. Social media based on internet technology has changed the pattern of information dissemination that was previously one to many audiences, to many audiences to many audiences [17].

Social media marketing or often called social media marketing is a form of direct or indirect marketing that is used to build awareness, recognition, memory, and actions for brands, businesses, products, people, or other parties and is carried out using tools from the social Web such as sharing blogging, microblogging, social networking, social bookmarking, and content [8]. According [8] the most common goals of social media, namely: (1) building relationships, (2) building brands, (3) publicity, (4) promotion, and (5) market research. Next [8] also mentioned that there were four pillars of social media marketing, including: reading, creating, sharing, and discussion.

\section{2. Online Knowledge Sharing Behavior}

The development of social media is currently causing changes in the behavior of someone who used to love sharing information in an all-round online. Share is an important measurement of viral marketing success, especially on social networking sites and refers to the level at which users exchange, distribute and receive content [12] In the form of social relations, share behavior often involves the exchange of content and information between people. In some cases, sharing behavior is often associated with relationships between people [7]. Even so there are doubts among researchers regarding the role of online knowledge sharing through social interactions using social media [14]. Through his research, [14] examined the motivations for online knowledge sharing behavior consisting of perceived online attachment motivation, perceived online relationship commitment, and altruism. Several previous studies have examined the factors which influencing on sharing behavior (passing) on viral messages and emails that are commercial [5]. These studies have identified several important factors that motivate a person to pass several written messages and viral commercials via email, which are caused by: social benefits, self-enrichment, entertainment (amusement), and attachment to friends.

\section{3. Factors of Individual Motivation and Social Media}

Motivation has become a research topic in social media, especially to explain why someone decides to join and use social media. On social networking sites like facebook, someone is motivated because of social connectivity and communication with friends [2]. According to [13] observed that someone is motivated to use social networking sites to get the benefits of selfenjoyment, get the benefits of these sites, and build a network. Social media is useful as a tool to improve student learning, look for ideas, and at the same time establish relationships in the context of learning between students and teachers [15]. But in the work environment, motivation for wanting to establish relationships, be useful, and desire to share personally and professionally, is the motivation that underlies someone using social media [4]. But most research still focuses on the underlying motivation for joining social media. Relatively little research has focused on motivation to knowledge sharing or social support provided through social media. Previously, [18] found that cognitive elements (e.g. learning new things and intellectual challenges) and affective elements (e.g. pleasure) were motivation factors that were positively related to sharing behavior on Wikipedia.

\section{4. Individual Performance}

There are many factors that influence knowledge sharing behavior both at the inter-organizational level and the interpersonal level. While the focus of this research is on the personal level so knowledge sharing between organizational levels is beyond the scope of this research. [3] examined various factors that influence individual knowledge sharing. [3] using reasoned-action theory supports the argument that extrinsic motivation, social psychology factors, and organizational factors influence an individual's intention to share knowledge. But it can't be denied that the information needed to generate the intention to share knowledge on an individual basis is very difficult to obtain [6] which is why knowledge sharing systems are applied more in various fields of the organization than at the individual level. So it is very important to identify the impact on individual performance. 


\subsection{Hypothesis Development}

The literature on content sharing is now widely available and is strong enough to explain the social and psychological factors that influence sharing behavior on social media. [16] categorize 10 (ten) motivational factors that can explain sharing behavior, namely: enjoyment, self-efficacy, learning, personal gain, altruism, empathy, community interest, social attachment, reputation and reciprocity. However, when a number of theories are proposed to explain why people engage in interpersonal communication, most research adopts the conceptual framework proposed by [21] because it provides a useful framework for integrating various motivations that potentially underlie online content delivery. Specifically, [21] proposed three dimensions of interpersonal behavior theory which he called FIRO (Fundamental Interpersonal Relations Orientation0. [21] suspects that people are bound in interpersonal communication because they are motivated to express one or more of three interpersonal needs which are: inclusion (need to be part of a group / need for attention), affection (showing respect and care for others), and control (showing feelings of competition, achievement, and influence in one's social environment). However, how these dimensions of interpersonal behavior theory relate to online content forwarding behavior is not yet clear. Therefore [11] summarize some of the literature to specifically identify motivations related to these three dimensions in an online context and support their research: motivational factors as measured from need to belong, altruism, personal growth affect knowledge sharing through online media, Therefore, this study proposes the following hypothesis:

$\mathrm{H} 1$ : Need to belong has a positive effect on online knowledge sharing behavior.

$\mathrm{H} 2$ : Altruism has a positive effect on online knowledge sharing behavior.

H3 : Personal growth has a positive effect on online knowledge sharing behavior.

Organizational skills that lead to the creation and effective sharing of knowledge are important components for an organization's competitive advantage. Furthermore, it is very important to find the relationship between knowledge sharing activities on successful performance, especially in the context of higher education institutions. [19] found a significant relationship between knowledge sharing and organizational financial performance. [9] found that efficiency in knowledge sharing resulted from shorter network paths related to the initial completion of the project compared to divisions with longer network paths. [23] found that knowledge acquisition was positively related to new product development and technological specificities and negatively related to sales costs. Current studies explore the effects on knowledge sharing in an academic environment. So based on the findings above can be it was hypothesized that knowledge sharing would have the same impact in the academic environment.

H4 : Online knowledge sharing behavior has a positive effect on individual performance.

\section{III.METHOD}

This type of research is quantitative research with causal nature. The location chosen in this study is the students from universities in Surabaya, East Java, Indonesia. The population in this study were all students from universities in Surabaya, East Java, Indonesia who met the criteria using social media to knowledge sharing, with a total sample of 120 respondents using the non random sampling method and purposive sampling. Data analysis using path analysis.

\section{IV.RESULT}

Table 1 shows that the corrected item total correlaction results for each statement item are above the number 0.300 . Then the answers given by respondents in each item statement declared valid. Based on the table 1 also shows the results of cronbach's alpha of above 0.700 . Then it can be concluded that the variables are in a reliable condition.

Tabel 1. Validity and Reliability Test

\begin{tabular}{|c|c|c|}
\hline Item & Validity Test & Reliabilitily Test \\
\hline $\mathrm{X} 1.1$ & 0,552 & \multirow{8}{*}{0.852} \\
\hline $\mathrm{X} 1.2$ & 0,567 & \\
\hline $\mathrm{X} 1.3$ & 0,688 & \\
\hline $\mathrm{X} 1.4$ & 0,592 & \\
\hline $\mathrm{X} 1.5$ & 0,532 & \\
\hline $\mathrm{X} 1.6$ & 0,464 & \\
\hline $\mathrm{X} 1.7$ & 0,640 & \\
\hline $\mathrm{X} 1.8$ & 0,656 & \\
\hline
\end{tabular}


International Journal of Advances in Scientific Research and Engineering (ijasre), Vol 6 (2), February-2020

\begin{tabular}{|c|c|c|}
\hline X1.9 & 0,703 & \multirow{4}{*}{0.789} \\
\hline $\mathrm{X} 2.1$ & 0,667 & \\
\hline $\mathrm{X} 2.2$ & 0,591 & \\
\hline $\mathrm{X} 2.3$ & 0,644 & \\
\hline X3.1 & 0,689 & \multirow{11}{*}{0.909} \\
\hline $\mathrm{X} 3.2$ & 0,666 & \\
\hline X3.3 & 0,763 & \\
\hline X3.4 & 0,441 & \\
\hline X3.5 & 0,681 & \\
\hline X3.6 & 0,657 & \\
\hline $\mathrm{X} 3.7$ & 0,634 & \\
\hline X3.8 & 0,555 & \\
\hline X3.9 & 0,803 & \\
\hline $\mathrm{X} 3.10$ & 0,777 & \\
\hline X3.11 & 0,736 & \\
\hline $\mathrm{Z} 1.1$ & 0,805 & \multirow{4}{*}{0.907} \\
\hline $\mathrm{Z1.2}$ & 0,859 & \\
\hline $\mathrm{Z1.3}$ & 0,865 & \\
\hline $\mathrm{Z1.4}$ & 0,674 & \\
\hline $\mathrm{y} 1.1$ & 0,769 & \multirow{5}{*}{0,880} \\
\hline $\mathrm{y} 1.2$ & 0,700 & \\
\hline $\mathrm{y} 1.3$ & 0,759 & \\
\hline y1.4 & 0,584 & \\
\hline y1.5 & 0,752 & \\
\hline
\end{tabular}

Tabel 2. R-Square $\left(\mathbf{R}^{2}\right)$ Value

\begin{tabular}{|l|l|}
\hline & Estimate \\
\hline Knowledge Sharing & 0,252 \\
\hline Individual Performance & 0,197 \\
\hline
\end{tabular}

Based on the table 2, it can be seen that the coefficient valuedetermination $\left(\mathrm{R}^{2}\right)$ need to belong, altruism, personal growth on online knowledge sharing $\left(\mathrm{R}^{2} 1\right)$ obtained by 0.252 , which means the influence of online knowledge sharing variables caused by the contribution of need to belong, altruism, personal growth of $25.2 \%$. While the value of the coefficient of determination $\left(\mathrm{R}^{2} 1\right)$ of online knowledge sharing on individual performance $\left(\mathrm{R}^{2} 2\right)$ obtained by 0.197 , which means the influence of individual performance variables caused by the contribution of online knowledge sharing variables of 19.7\%. The accuracy of the model from the research data can be measured based on the relationship of the coefficient of determination $\left(\mathrm{R}^{2}\right)$ in both equations. The calculation of the accuracy of the model is done through the formula $R^{2}$ model $=1-\left(1-R^{2} 1\right)\left(1-R^{2} 2\right)$ with the result that is $39.9 \%$ known that the contribution of the model to explain the structural relationship of the five variables examined in this study amounted to $39.9 \%$ and the rest of the results amounted to $60.1 \%$ explained by other variables not involved in the model. From the R-Square results also can be concluded that the proposed model isrobust and hypotheses can be tested. The research structure model can be explained on figue 1 . 
42.31

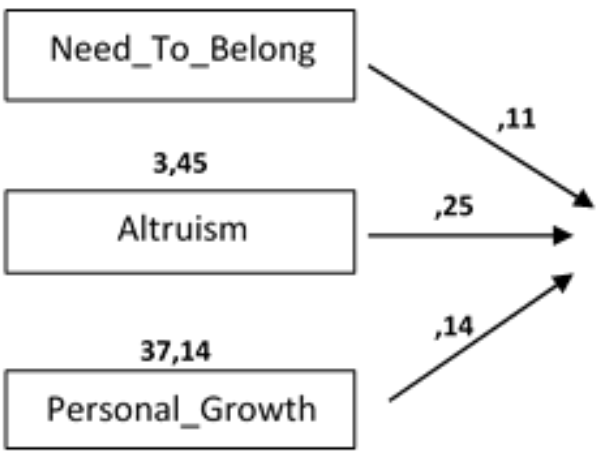

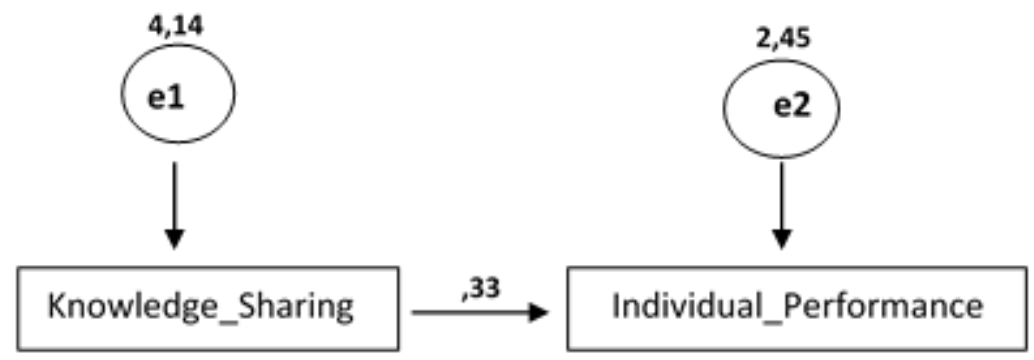

Figure1.

\section{Research Structure Model}

Based on figure 1 it can be converted into structural model equations. To calculate the values of e1 and e2 the formula e $=\sqrt{ } 1-r 2$ is used. The structural model equations in this study are as follows:

$$
\begin{aligned}
& \mathrm{e} 1=\sqrt{ } 1-\mathrm{r} 1^{2} \rightarrow \mathrm{e} 1=\sqrt{ } 1-0,252=\sqrt{ } 0,748=0,865 \\
& \mathrm{e} 2=\sqrt{ } 1-\mathrm{r} 2^{2} \rightarrow \mathrm{e} 1=\sqrt{ } 1-0,197=\sqrt{ } 0,803=0,896 \\
& \mathrm{Z}=\mathrm{b} 1 \cdot \mathrm{X}_{1}+\mathrm{b} 2 \cdot \mathrm{X}_{2}+\mathrm{b} 3 \cdot \mathrm{X}_{3}+\mathrm{e}_{1} \\
& \mathrm{Z}=0,11 \mathrm{X}_{1}+0,25 \cdot \mathrm{X}_{2}+0,14 \cdot \mathrm{X}_{3}+0,865 \\
& \mathrm{Y}=\mathrm{b} 4 \cdot \mathrm{Z}+\mathrm{e}_{2} \\
& \mathrm{Y}=0,33 \mathrm{Z}+0,896
\end{aligned}
$$

The relationship of need to belong on online knowledge sharing showed in table 3, and the result is those relationship get a calculated CR value of 3.396> 2.00 and a significance value of $0.000<0.05$. The relationship between altruism on online knowledge sharing gets a calculated CR value of 2.230> 2.00 and a significance value of $0.026<0.05$. The relationship of personal growth on online knowledge sharing get a calculated CR value of 4.097> 2.00 and a significance value of $0.000<0.05$ The relationship of online knowledge sharing on individual performance (student academic achievement) gets a calculated CR value of $4.928>2.00$ and a significance value of $0.000<0.05$

Tabel 3. Hypotheses Testing

\begin{tabular}{|l|l|l|l|l|}
\hline & \multicolumn{1}{|c|}{ Estimate } & \multicolumn{1}{|c|}{ C.R } & \multicolumn{1}{c|}{ P } & \multicolumn{1}{c|}{ Hypothesis } \\
\hline H1 (NB >KS) & 0,107 & 3,396 & 0,0000 & Supported \\
\hline H2 $($ AT $->$ KS $)$ & 0,245 & 2,230 & 0,26 & Supported \\
\hline H3 (PG >KS) & 0,137 & 4,097 & 0,0000 & Supported \\
\hline H4 $($ KS $->$ IP) & 0,329 & 4,928 & 0,0000 & Supported \\
\hline
\end{tabular}

After knowing the effect of one variable on other variables, the next step is to know the direct effect, indirect effect, and the total effect of an exogenous variable on endogenous variables. The results of direct influence, indirect influence, and the total effect of variables in this study can be seen in table 4 . 
International Journal of Advances in Scientific Research and Engineering (ijasre), Vol 6 (2), February-2020

Tabel 4. Standardized Direct Effects Test Results, Standardized Indirect Effects, and Standardized Total Effects

\begin{tabular}{|l|l|c|c|c|c|}
\hline & $\begin{array}{c}\text { Need to } \\
\text { belong }\end{array}$ & Altruism & $\begin{array}{c}\text { Personal } \\
\text { Growth }\end{array}$ & $\begin{array}{c}\text { Online } \\
\text { Knowledge } \\
\text { Sharing }\end{array}$ \\
\hline \multirow{2}{*}{$\begin{array}{l}\text { Standardized } \\
\text { Direct Effects }\end{array}$} & $\begin{array}{l}\text { Online } \\
\text { knowledge } \\
\text { sharing }\end{array}$ & 0,295 & 0,194 & 0,356 & 0,000 \\
\cline { 2 - 6 } & $\begin{array}{l}\text { Individual } \\
\text { performance }\end{array}$ & 0,000 & 0,000 & 0,000 & 0,000 \\
\hline \multirow{3}{*}{$\begin{array}{l}\text { Standardized } \\
\text { Indirect Effects }\end{array}$} & $\begin{array}{l}\text { Online } \\
\text { knowledge } \\
\text { sharing }\end{array}$ & 0,000 & 0,000 & 0,000 & 0,000 \\
\cline { 2 - 6 } & $\begin{array}{l}\text { Individual } \\
\text { performance }\end{array}$ & 0,158 & 0,86 & 0,131 & 0,000 \\
\hline \multirow{2}{*}{$\begin{array}{l}\text { Standardized } \\
\text { Total Effects }\end{array}$} & $\begin{array}{l}\text { Online } \\
\text { knowledge } \\
\text { sharing }\end{array}$ & 0,295 & 0,194 & 0,356 & 0,000 \\
\cline { 2 - 6 } & $\begin{array}{l}\text { Individual } \\
\text { performance }\end{array}$ & 0,131 & 0,86 & 0,158 & 0,444 \\
\hline
\end{tabular}

Based on table 4, it can be seen that the results of direct influence, indirect effect, and the total effect between variables. The results of direct influence in this study can be seen in the value of standardized direct effects which shows the value of the direct effect of need to belong to knowledge sharing was 0.295 and the direct effect on individual performance was 0,000 . The direct effect of altruism on online knowledge sharing was 0.194 and the direct effect on individual performance was 0,000 . The direct effect of personal growth on knowledge sharing was 0.356 and the direct effect on individual performance was 0,000 . Then the direct effect of knowledge sharing on individual performance was 0.444 . Furthermore, to determine the value of the indirect effect of the variable can be seen in the value of the standardized indirect effect. The value of the indirect effect of need to belong to individual performance was 0.131 and the value of the indirect effect of altruism on individual performance was 0.086 and the value of the indirect effect of personal growth on individual performance was 0.158 . Then the direct effect of online knowledge sharing on individual performance was 0,000 . Meanwhile, to determine the total effect between variables can be calculated by the value of the direct effect added to the indirect effect or can be directly seen in the standardized total effects table. Based on the standardized total effetcs, it can be seen that the effect of the total variable need to belong on individual performance was 0.131 , the effect of total altruism variables on individual performance is 0.086 , and the effect of total personal growth variables on individual performance was 0.158 . Based on these results, it can be explained that the value of standardized direct effects need to belong, altruism, and personal growth on online knowledge sharing are greater than the value of the variable effects need to belong, altruism, and personal growth on individual performance. That is, online knowledge sharing variables cannot be independent variables and mediation variables or knowledge sharing variables cannot be independent variables.

\section{DISCUSSION}

In accordance with the results of the analysis conducted by researchers, researchers obtain results that need to belong has an effect on knowledge sharing. These results are supported by research results from [11] which states that the need to belong motivation factors influence online. sharing behavior This shows that need to belong among academic members in a social network has a positive effect on online knowledge sharing behavior through online media. Beside that researchers obtained results that altruism influence knowledge sharing. These results are supported by research results from [11] which states that altruism motivation factors influence online behavior sharing. This shows that the factor of helping others (altruism) among academic members in a social network positively influences on online knowledge sharing behavior. Researchers also obtain results that personal growth affects knowledge sharing. These results are supported by the results of research from [11] which states that personal growth motivational factors influence on online knowledge sharing behavior. This shows the factor of desire for growth (personal growth) among academic members in a social network affect on online knowledge sharing behavior 
Finally, the last hyphotheses said a positive effect on individual performance (in this case student academic achievement) supported by the research of [19]who found a significant relationship between knowledge sharing and individual performance. This shows that the personal growth motivation of the students from universities in Surabaya, East Java, Indonesia. in terms of sharing knowledge through online media is very enthusiastic

\section{REFERENCES}

[1] Allsop, Dee T., Bryce R. Bassett, and James A. Hoskins (2007), Word-of-Mouth Research: Principles and Applications, Journal of Advertising Research, 47, 388-411.

[2] Barker, V. (2009). Older Adolescents' Motivations for Social Network Site Use: The Influence of Gender, Group Identity, and Collective Self-Esteem. Cyber Psychology \& Behavior, 12(2), 209-213.

[3] Bock, G. W., Zmud, R. W., Kim, Y. G., \& Lee, J. N. (2005). Behavioral intention formation in knowledge sharing: Examining the roles of extrinsic motivators, socialpsychological forces, and organizational climate. MIS Quarterly, 29(1), 87-111.

[4] DiMicco, J., Millen, D. R., Geyer, W., Gugan, C., Brownholtz, B. \& Muller, M. (2008). Motivations for social networking at work. Proceedings of the 2008, IBM Conference, Cambridge, Massachusetts.

[5] Dobele, A., Lindgreen, A., Beverland, M., Vanhamme, J. \& Van Wijk, R. (2007), Why Pass on Viral Messages? Because They Connect Emotionally. Business Horizons, Vol. 50 No. 4, pp. 291-304

[6] Dosi, G., \& Orsengio, L. (1988). Coordination and transformation: an overview of structures, behaviors and change in evolutionary environments. Technical change and economic theory, London .

[7] Engeström, Y. (2001). Expansive learning at work: Toward an activity-theoretical conceptualization. Journal of Education and Work, 14(1), 133-156

[8] Gunelius, S. (2011). 30 Minute Social Media Marketing: Step By Step Techniques to Spread The Word About Your Business Fast And Free. United States: McGraw-Hill

[9] Hansen, M. T. (2002). Knowledge networks: Explaining effective knowledge sharing in multiunit companies. Organization Science, 13(3), 232-248.

[10] Hayes. Jameson L.. \& King, Karen Whitehill. (2014). The Social Exchange of Viral Ads: Referral and Coreferral of Ads Among College Students. Journal of Interactive Advertising, 0(0), 1-1

[11]Ho, J. Y. C., and M. Dempsey. (2010). Viral Marketing: Motivations to Forward Online Content. Journal of Business Research 63, 9/10: 1000-1006.

[12] Kietzmann JH, Hermkens K, McCarthy IP, Silvestre BS. (2011). Social Media? Get Serious! Understanding The Functional Building Blocks of Social Media. Business Horizons 54 (3): 241-251

[13]Lin, Kuan-Yu \& Hsi-Peng Lu. (2011). Why People Use Social Networking Sites: An Empirical Study Integrating Network Externalities and Motivation Theory. Computers in Human Behavior, 27, 3, 1152-61.

[14] Ma, Will. W. K dan Chan, Albert. (2014). Knowledge sharing and social media: Altruism, perceived online attachment motivation, and perceived online relationship commitment, Computer in Human behavior, 39: 51-58

[15] Mazer, J. P., Murphy, R.E., \& Simonds, C.J. (2007). I'll see you on Facebook: The Effects of Computer-Mediated Teacher Self-Disclosure on Student Motivation, Affective Learning, and Classroom Climate'. Communication Education, 56:1, 1-17.

[16] Oh, S., \& Syn, S. Y. (2015). Motivations for Sharing Information and Social Support in Social Media : A Comparative Analysis of Facebook, Twitter, Delicious, YouTube, and Flickr. Journal Of The Association For Information Science And Technology, 66(April), 2045-2060.

[17] Paramita, E. L. and Haryanto, J. O. 2011. The Market Segment of Children in Indonesia; A Study of the Influence of Brand Credibility, Emotional Bonding and Autobiographical Memory on the Intention to Consume. Proceedings 6th International Conference on Business and Management Research (The MRC Doctoral Journey in Management), held by University of Indonesia and The Ateneo de Manila Graduate School, Philippines on October 27-28, 2011 in Makati, Philippines. 39

[18] Rafaeli, A., Ziklik, L. and Doucet, L (2008) 'The impact of call center employees' customer orientation behaviors on service quality’, Journal of Service Research, 10(3): 239- 255.

[19] Rhodes, J., Lok, P., Hung, R. Y. Y., \& Fang, S. C. (2008). An integrative model of organizational learning and social capital on effective knowledge transfer and perceived organizational performance. Journal of Workplace Learning, $20(4), 245$ - 258.

[20]Rong Du, Shizhong Ai \& Yuqing Ren. (2007). Relationship between knowledge sharing and performance: A survey in Xi'an, China. Expert Systems with Applications. 32: 38-46

[21] Schutz WC. (1966). FIRO: A Three Dimensional Theory of Interpersonal Behavior. NewYork: Holt,Rinehart, \& Winston

[22] Tobin, J. I Braziel, L. (2008): Social Media Is A Cocktail Party: Why You Already Know The Rules Of Social Media Marketing, CreateSpace (2008).

[23] Yli-Renko, H., Autio, E., \& Sapienza, H. J. (2001). Social capital, knowledge acquisition, and knowledge exploitation in young technology-based firms. Strategic Management Journal, 22(6-7), 587-613.

[24]Zarrella D (2010). The Social media marketing. O’Reilly Media, Inc. 